\title{
DENSITY OF WOOD OF PINE AND SPRUCE IN THE POSTAGROGENIC SOIL OF THE BOREAL ZONE
}

\author{
Sergey Janusz, Dmitry Danilov \\ Leningrad Scientific Research Institute of Agriculture "BELOGORKA", Russia \\ btkwood@mail.ru; stown200@mail.ru
}

\begin{abstract}
The aim of this research was to study the effect of the stand composition on the density of pine and spruce wood growing on former arable lands. Sample areas are located in mixed mature pine- and spruce-prevailing stands in Leningrad region, Russia. For the reliable determination of the basic density of spruce and pine wood, selection of model trees was carried out and cores were taken. Based on the data obtained from stems of 36 model trees from 3 sample plots, conversion equations were calculated to determine the basic density of wood. The measurements of the spruce and pine wood density were processed using variational statistics. The results have shown that the pine forms a more homogeneous wood than the spruce. On former arable lands, spruce has a denser wood than pine under the same growth conditions. The stand composition has a significant effect on the density of spruce rather than pine. Key words: former arable land, taxation indicators, stands of spruce and pine, basic density of wood.
\end{abstract}

\section{Introduction}

The quantitative parameters of pine and spruce stock in plantations growing on postagrogenic lands have been discussed in a number of publications (Johansson, 1996; Ruskule et al., 2012; Daugaviete, 2015; 2017; Golubeva, 2015). However, the quality of pine and spruce wood in the European boreal zone was studied mainly in stands on forest lands. A number of works concerned with this subjectmatter were published by authors from Scandinavian countries (Pikk, 1996; Zianis, 2005; Jyske, 2008). There are some publications on the quality of wood in postagrogenic lands in the North-West region of Russia (Golubeva, Lokhov, \& Danilov, 2015). The stands of pine and spruce growing on the former arable land are notable for a greater forest yield in comparison with stands growing on forest lands (Алятин, 2006). The quantitative characteristics of these stands have an impact on the quality characteristics of pine and spruce wood growing on post-agrogenic soil (Danilov et al., 2016). The investigations of physical and mechanical properties of pine and spruce wood growing on fallow land give various, often contradictory, conclusions (Голубева, Лохов, \& Данилов, 2015). Therefore, the research in this area is of undoubted interest for practice and theory of forest environmental research. Since no studies have been conducted on the quality of spruce and pine wood for the conditions of the North-West region of Russia so far, the purpose of the research was to study the specific features of the pine and spruce wood density formation in postagrogenic lands.

\section{Materials and Methods}

We have investigated 3 sites in the former arable lands with a stand of mature mixed trees of spruce and pine up to $80-85$ years of age. The subjects of research are located in the south-west of the Leningrad Region in the Gatchina District (59²0'07.84'N $30^{\circ} 09^{\prime} 12.35^{\prime \prime E ~ / ~ 59 ॰ 20 ' 17.8 ” N ~ 3009 ' 20 ” E) . ~ T h e ~}$ soils represent a degraded agrozem covered with a humus horizon layer with presence of podsol 10 $12 \mathrm{~cm}$ in thickness formed during formation of forest community. The underlying bed is a double-layer one, consisting of a red-colored moraine loam covered with a sandy loam horizon. The growing conditions of the region under investigation correspond to the I-Ia growth class.

We selected the total of 36 model trees on 3 sample plots according to the most representative diameter class of the stands to determine the basic density of pine and spruce wood. The basic density of wood is a calculated index that is easily normalized to calculate the density of wood with any moisture content. According to the method of Poluboyarinov (1983), the trunks of model trees were sawn up, the length of the pieces was $10 \%$ of the model tree height. Samples of wood were taken from each model tree using the whole cross-cut section of the wood. Another sample was taken at a height of $1.3 \mathrm{~m}$ as the taxation diameter. The basic density of wood was determined by the Poluboyarinov (1976) method of maximum moisture saturation of wood samples (equation 1):

$$
\rho_{b}=\frac{1}{\frac{m_{w}-m_{0}}{m_{0}}+\frac{1}{d}}, \mathrm{~g} \mathrm{~cm}^{-3}
$$

where

$d$ - wood substance density $1.53 \mathrm{~g} \mathrm{~cm}^{-3}$, $m_{w}$ - weight of the absolutely wet sample, $m_{0}$ - weight of the absolutely dry sample.

Further, a conversion equation was composed. It showed relation between the wood density at the level of $1.3 \mathrm{~m}$ and average density of the trunk wood. This allows further to use the wood cores taken at this height to determine the density of the entire trunk without tree felling and crosscutting. 


\section{Average taxation characteristic values of stand of mixed trees of spruce and pine growing on the postagrogenic soil}

\begin{tabular}{|c|c|c|c|c|c|}
\hline \multicolumn{6}{|c|}{ Object of research \#1 with spruce predominance } \\
\hline Species & Content,\% & A, years & $\mathrm{D}_{\mathrm{av}}, \mathrm{cm}$ & $\mathrm{H}_{\mathrm{av}}, \mathrm{m}$ & $\mathrm{M}, \mathrm{m}^{3}$ \\
\hline Spruce & 80 & 80 & 28.9 & 28.8 & 288 \\
\hline Pine & 18 & 85 & 39.6 & 28.4 & 64 \\
\hline Aspen & 1 & 50 & 27.9 & 25.5 & 3 \\
\hline Birch & 1 & 60 & 23.1 & 24.2 & 4 \\
\hline \multicolumn{6}{|c|}{ Object of research \#2 with predominance of spruce } \\
\hline Spruce & 55 & 80 & 27.1 & 28.2 & 309 \\
\hline Pine & 38 & 85 & 35.2 & 27.8 & 215 \\
\hline Aspen & 5 & 50 & 29.3 & 25.7 & 27 \\
\hline Birch & 2 & 60 & 18.0 & 21.6 & 14 \\
\hline \multicolumn{6}{|c|}{ Object of research \#3 with predominance of pine } \\
\hline Spruce & 59 & 85 & 31.2 & 27.4 & 269 \\
\hline Pine & 32 & 80 & 21.8 & 25.4 & 148 \\
\hline Aspen & 4 & 50 & 33.8 & 26.2 & 18 \\
\hline Birch & 5 & 60 & 24.6 & 24.7 & 22 \\
\hline
\end{tabular}

Calculation of the average basic density of wood for the stand consisting of spruce and pine trees was made as the average weighted value, depending on the diameter class of trees represented within this stand.

A suite of applied computer programs was used to detect significant differences. The Statistica 11 program was used for statistical processing.

\section{Results and Discussions}

On the basis of the samples selected from the model trees, the conversion equations $(2,3)$ were obtained to calculate the basic density of the wood of the core samples selected by the Pressler's borer at the height of $1.3 \mathrm{~m}$ above soil surface $(x)$ for the entire tree trunk $(y)$. The calculated equations have a high level of determination $\left(R^{2}\right)$.

$$
\text { for pine: } y=1.00 x-45.87, R^{2}=0.70
$$

for spruce: $y=0.92 x+28.22, R^{2}=0.93$

On the basis of the cores of wood selected from the represented trees according to the stand diameter class, calculation of the average basic wood density according to the diameter class was made. For a reliable analysis of the wood density, the coefficient of variation $\left(C_{v}\right)$ of this index was calculated for determination of the required number of cores. The coefficient of variation less than $10 \%$ indicates a weak variability of the characteristic and from 10 to $20 \%$ indicates an average one (4).

$$
C_{v}=\sigma / M \pm 100 \% \text {, }
$$

where $M$ - arithmetic mean value, $\sigma-$ mean square deviation.

About 6-12 measurements by Student t-test with $C_{v} 5-11 \%$ are required for reliable analyses with $t_{\text {table }}=2.6, p$-value $=0.9$ (Freedman, 2005).

The density of wood is a deterministic feature and therefore the variability is not high, as data in Table 3 shows.

The variability of spruce wood density was higher on average than that of pine. Apparently, this can be explained by a greater representation of spruce trees in a more extended row by the diameter class than in the pine part of the stand at the research objects.

Table 2

Coefficient of variation of the wood density of pine and spruce trees on the research objects $\left(C_{v}, \%\right)$

\begin{tabular}{|l|c|c|c|}
\hline \multicolumn{1}{|c|}{ Species of wood } & Object 1 & Object 2 & Object 3 \\
\hline Spruce & 9 & 11 & 6 \\
\hline Pine & 6 & 5 & 6 \\
\hline
\end{tabular}


Basic density of spruce and pine wood at the research objects $\left(\mathrm{kg} \mathrm{m}^{-3}\right)$

\begin{tabular}{|c|c|c|c|c|c|c|c|c|c|c|}
\hline Diameter class, cm & 12 & 16 & 20 & 24 & 28 & 32 & 36 & 40 & 44 & 48 \\
\hline \multicolumn{11}{|c|}{$\# 1$} \\
\hline \multirow{2}{*}{ Spruce } & 412 & 397 & 406 & 360 & 356 & 382 & 389 & 436 & 366 & 412 \\
\hline & 448 & 446 & 383 & 356 & 385 & 373 & 360 & $409 / 418$ & 341 & 448 \\
\hline \multirow{2}{*}{ Pine } & - & - & 376 & 384 & 413 & 419 & 392 & 387 & 376 & 379 \\
\hline & - & - & - & - & 373 & 393 & 374 & 381 & 367 & 387 \\
\hline \multicolumn{11}{|c|}{$\# 2$} \\
\hline \multirow{2}{*}{ Spruce } & 406 & 462 & 445 & 383 & 408 & 437 & 427 & - & - & - \\
\hline & 564 & 407 & 435 & 390 & 449 & 459 & - & - & - & - \\
\hline \multirow{2}{*}{ Pine } & - & - & - & 396 & 348 & 404 & 367 & 377 & 374 & 323 \\
\hline & - & - & - & 360 & 381 & 370 & 351 & 380 & 396 & 377 \\
\hline \multicolumn{11}{|c|}{$\# 3$} \\
\hline \multirow{2}{*}{ Spruce } & 414 & 382 & $\frac{373}{365}$ & $\frac{377}{397}$ & 420 & 446 & 357 & 412 & - & - \\
\hline & $\frac{411}{389}$ & $\frac{373}{366}$ & $\frac{399}{382}$ & 387 & 379 & - & - & - & - & - \\
\hline \multirow{2}{*}{ Pine } & & & 372 & 356 & 409 & 364 & 358 & 391 & 398 & 372 \\
\hline & - & - & 353 & 364 & 404 & 369 & 382 & 366 & 324 & 353 \\
\hline
\end{tabular}

For the investigated stands growing on the former arable land, one can observe an interesting regularity. The spruces have a higher density of wood than the pine storey of the stand (Table 3).

It should be noted that according to the different estimates, a similar pattern has been observed on the forest lands within the research region (Danilov, 2014; 2016).

However, according to the data of other authors, the basic density of pine wood is $400-412 \mathrm{~kg} \mathrm{~m}^{-3}$ and the basic density of spruces is $380-390 \mathrm{~kg} \mathrm{~m}^{-3}$ (Poluboyarinov, 1976; Smirnov, 2006).
At the same time, studies of the wood density of pines and spruces carried out in the plantation crop of pines and spruces located in the former hayfields and arable lands in the Leningrad and Pskov regions also showed that the density of wood is higher in spruce stands (Stepanenko, 2014; Danilov, 2017). This fact can be considered as demonstration of a different growth response.

The pines with their pioneering growth strategy are characterized by an accelerated growth of xylem thanks to the area of early wood in the annual growth in these conditions on the former arable lands.

Table 4

ANOVA analysis of the significant difference between wood density of pine and spruce

\begin{tabular}{|c|c|c|c|c|c|c|}
\hline Dispersion & $\begin{array}{l}\text { Sum of } \\
\text { squares }\end{array}$ & $\begin{array}{l}\text { Degree of } \\
\text { freedom }\end{array}$ & $\begin{array}{l}\text { Average } \\
\text { square }\end{array}$ & $\begin{array}{c}\text { Actual Fisher's } \\
\text { variance ratio } F a\end{array}$ & $\begin{array}{l}\text { Theoretical } \\
\text { Fisher's variance } \\
\text { ratio } F_{t}, p=1 \%\end{array}$ & $\begin{array}{c}\text { Null hypothesis } \\
\text { acceptance } \\
\text { probability }\end{array}$ \\
\hline \multicolumn{7}{|c|}{ For the pine } \\
\hline Total & 81311.31 & 41 & & \multirow{3}{*}{0.987406} & \multirow{3}{*}{5.194413} & \multirow{3}{*}{3.238096} \\
\hline Variants & 22541.54 & 2 & 406.1438 & & & \\
\hline Residual & 58769.77 & 39 & 411.324 & & & \\
\hline \multicolumn{7}{|c|}{ For the spruce } \\
\hline Total & 81311.31 & 49 & & \multirow{3}{*}{9.013581523} & \multirow{3}{*}{5.087373} & \multirow{3}{*}{0.000486} \\
\hline Variants & 22541.54 & 2 & 11270.77 & & & \\
\hline Residual & 58769.77 & 47 & 1250.421 & & & \\
\hline
\end{tabular}


The spruces have a more tolerant growth strategy, the xylem is formed in the areas of early and late wood in the annual growth. The previous studies have shown that in the improved conditions of growing or fertilizing, the pine actively increases the early wood area in its annual ring, while the spruce increases the growth of the late wood area in its annual growth (Danilov, 2012).

The average basic density of the pine wood within the pine cenosis is $376-382 \mathrm{~kg} \mathrm{~m}^{-3}$ and in fact the share of its presence in the stand does not affect this indicator. Taking into account the predominance of the spruce in the stand (research object 1), it has a smaller average basic density for the stand of $393 \mathrm{~kg} \mathrm{~m}^{-3}$ in comparison with the stand with a larger content of pine, where the spruce wood density is $436 \mathrm{~kg} \mathrm{~m}^{-3}$.

As to the spruce part of the stands, the share of its presence affects the density of wood significantly that was confirmed by the ANOVA (analysis of variance)
(Table 4). As to the pine, no statistically significant difference between these research objects was found. Thus, the pine forms wood with more uniform density than the spruce does on the post-acrogenic soil regardless the stand composition.

\section{Conclusions}

According to the results of the study of mixed spruce and pine stands growing on postagrogenic lands, the following conclusions can be drawn:

1. The stand content has a significant impact on the spruce wood density but not on the wood density of pine.

2. Pine forms wood with a more uniform density on old-arable lands than spruce does.

3. A denser wood of the spruce is formed on postagrogenic soil in comparison with the pine in the same growth conditions.

\section{References}

1. Alyatin, M.V. (2006). Особенности происхождения, формирования и воспроизводства сложных ельников (Specifics of origin, formation and reproduction of complex spruce forests of the Izhorsk (Silurian) plateau) Dissertation of the candidate of agricultural sciences. St. Petersburg: State Forestry Academy, 133 c. (in Russian).

2. Chibisov, G.A. (2010). Смена сосны елью (Change of pine by spruce) Arkhangelsk: Publishing house of Northern Research Institute of Forestry.150 c. (in Russian).

3. Danilov, D.A., Belyaeva, N.V., \& Melnikov, E.A. (2011). Результаты воздействия комплексного ухода на структуру и качество показателей древесины сосново-елового древостоя. (The results of the impact of complex care on the structure and quality of indicators of wood pine-spruce stands). Bulletin of Saratov State Agriculture University named after Vavilov. 8, 3-8. (in Russian).

4. Danilov, D.A., Zhigunov, A.V., Krasnovidov, A.N., Ryabinin, B.N., Neverovsky, V.Yu., \& Anders (2016). Выращивание древесных насаждений на постагрогенных землях О.O. (Growing of tree stands on post-agrogenic lands) - Saint Petersburg: Publishing house of Polytechnic University, 130 c. (in Russian).

5. Danilov, D.A. (2015). Growing tree plantations of pine and spruce on the grounds postagrogenic Northwest. Towards a Sustainable Bioeconomy 21-23 October 2015, Sant Pau, Barcelona, 37-42.

6. Daugaviete, M., Lazdina, D., Bambe, B., Bardule, A., Bardulis, A., \& Daugavietis, U. (2015). Productivity of different tree species in plantations and agricultural soils and related environmental impacts. Baltic Forestry 21(2), 349-358.

7. Daugaviete, M., Lazdins, A., Lazdina, D., Makovskis, K., \& Daugavietis, U. (2017). Growth and yield of 15-year plantations of pine, spruce and birch in agricultural land - Rural sustainability research 37 (332), pp. 38-59. DOI: 10.1515/plua-2017-0005.

8. Freedman, D. (2005). Statistical Models: Theory and Practice. Cambridge University Press. 424p.

9. Golubeva, L.V. (2015). Лесоводственно-экологическая трансформация постагрогенных земель на карбонатных отложениях в подзоне средней тайги Архангельской области (Forestry-ecological transformation of postagrogenic lands on carbonate deposit soils in subzone of middle taiga of Archangelsk region). Doctoral thesis of agriculture sciences, Archangelsk, 160 c. (in Russian).

10. Johansson, T. (1996). Site index curves for Norway Spruce (Picea abies (L.) Karst.) planted on abandoned farm land. New Forests, 11: 9-29.

11. Jyske, T. (2008). The effects of thinning and fertilisation on wood and tracheid properties of Norway spruce (Picea abies) - the results of long-term experiments. Department of Forest Resource Management, Faculty of Agriculture and Forestry University of Helsinki, Academic dissertation, $59 \mathrm{p}$.

12. Korchagov, S.A., \& Melekhov, V.I. (2009). Влияние удобрений и комплексных уходов на формирование древесины сосны в лесных культурах (The effect of fertilizers and complex care on the formation of pine wood in forest cultures) "Izvestiya" Agricultural Academy named after Timiryazev. 2, 64-67. (in Russian). 
13. Lokhov, D.V. (2011). Лесоводственная оценка и показатели качества древесины культур сосны на залежных землях (Forestry assessment and quality indicators of pine wood in fallow lands) Ecological problems of the North. Interuniversity collection of scientific papers, Issue 14, 73-76. (in Russian).

14. Polubojarinov, O.I. (1976). Плотность древесины. (Wood density) - Moscow: Forest industry, 159 с. (in Russian).

15. Pikk, J., Kask, R., \& Peterson, P. (1996). The wood quality of fertilized Scots pine (Pinus sylvestris L.) stands on Vaccinium vitis-idaea and Cladonia site type. Metsanduslikud Uurimused 44, 9-19.

16. Ruskule, A., Nikodemus, O., Kasparinska, Z., Kasparinskis, R., \& Brūmelis, G. (2012). Patterns of afforestation on abandoned agriculture land in Latvia. Agroforestry Systems, 85, 215-231.

17. Smirnov, A.A. (2004). Влияние комплексного ухода на форму ствола и плотность древесины (Тhе influence of complex care on the shape of the trunk and the density of wood) Structure, properties and quality of wood. Proceedings of the IV International Symposium vol. I. - St. Petersburg: State Forestry Academy, 131-133. (in Russian).

18. Tsarenko, V.P., Danilov, D.A., \& Smirnov, A.P. (2014). Продуктивность и качество древесины смешанных елово-сосновых древостоев на почвах двучленного строения (Productivity and quality of wood of mixed spruce-pine stands on two-membered structure soils) 'Izvestiya' St. Petersburg State Agrarian University. 36, 55-60. (in Russian).

19. Zianis, D., Muukkonen, P., Mäkipää, R., \& Mencuccini, M. (2005). Biomass and stem volume equations for tree species in Europe. Silva Fennica, Monographs 4, 63 p. 